\title{
IDENTIFIKASI DAN PENETAPAN KADAR SILDENAFIL SITRAT PADA JAMU KUAT LELAKI YANG BEREDAR DI KOTA MAKASSAR
}

\author{
Risda Waris ${ }^{*}$, Abd. Kadir ${ }^{\star *}$, Chairil Akbar ${ }^{*}$ \\ *) Fakultas Farmasi Universitas Muslim Indonesia \\ ${ }^{* *}$ Fakultas Farmasi Universitas Hasanuddin \\ Email : risdawaris@gmail.com
}

\begin{abstract}
A studies have been conducted identifying and determining the levels of sildenafil citrate in men vitality herbs that marketed in twon of makassar. This study aims to determine the presence of drugs chemicals substances (BKO) in men vitality herbs that is sildenafil citrate with TLC-Densitometry method. Herbal samples extracted using methanol solvent. Identification test by thin layer chromatography (TLC) using a mobiloe phase of chloroform - ethanol $(9.5: 0,5)$ indicates that the herbal sample were compared with comparator compounds contains sildenafil citrate. Assay done using a TLC-Densitometry at a maximum wavelength of $292 \mathrm{~nm}$. The results showed levels of sildenafil citrate in men vitality herbs was 0,00827 $\mathrm{g} / 100 \mathrm{~g}$ or $0,00827 \%$ per capsule.
\end{abstract}

Key Words : Identifying, Determining, Sildenafil Citrate, Men Vitality Herbs

\section{PENDAHULUAN}

\begin{tabular}{lrr}
\multicolumn{1}{c}{ Obat } & tradisional & oleh \\
Departemen & Kesehatan \\
diklasifikasikan & sebagai & Jamu, \\
Fitofarmaka dan Taman & Obat
\end{tabular}

Keluarga (TOGA). Jamu adalah obat yang berasal dari bahan tumbuhtumbuhan, hewan dan mineral dan atau sediaan galeniknya atau campuran dari bahan-bahan tersebut yang digunakan dalam upaya pengobatan berdasarkan pengalaman (Ditjen POM, 2000).

Beberapa jamu mengandung herba yang memiliki senyawa aktif berkhasiat tertentu. Senyawa aktif tersebut bekerja mirip obat kimia, seperti mengatasi peradangan (antiinflamasi), melancarkan air seni (diuretik), menghilangkan rasa sakit (analgesik), dan membunuh bakteri (antibakteri). Bedanya, reaksi jamu dalam meredam gejala mungkin tidak sekuat obat kimia, sehingga memerlukan waktu lebih lama dan harus dikonsumsi dengan dosis khusus. Karena waktu yang dibutuhkan oleh obat herbal jauh lebih lama untuk menghasilkan efek yang dibutuhkan, banyak produsen obat 
jamu menambahkan bahan kimia obat kedalam produksi jamu untuk mempercepat terjadinya efek pengobatan. Berikut ini 9 obat kimia di balik "kemanjuran" jamu palsu (Najib, 2009). Jamu kuat lelaki yang beredar di kalangan masyarakat banyak yang telah ditambahkan Bahan Kimia Obat (BKO) yaitu Sildenafil Sitrat. Penggunaan Sildenafil Sitrat harus selalu dibawah pengawasan ketat dokter setelah ada diagnosa pasti tentang disfungsi ereksi. Penggunaan yang tidak dibawah pengawasan dokter dan atau tidak tepat dapat meningkatkan risiko efek yang tidak diinginkan antara lain gangguan penglihatan, gangguan pencernaan (dyspepsia), muntah, sakit kepala, reaksi hipersensitif dan priapism (ereksi berkepanjangan lebih dari 4 jam). Pada pasien dengan riwayat penyakit kardiovaskular dapat meningkatkan risiko kejadian infarkmiokard. Obat ini tidak boleh digunakan pada pasien yang sedang dalamterapi nitrat, pasien infark miokard, pasien yang tidak boleh melakukanaktivitas seksual, pasien yang baru mengalami stroke, angina yang tidakstabil dan tekanan darah dibawah 90/50 mm Hg (Ditjen POM, 2005). Sildenafil sitrat merupakan bahan aktif pertama yang digunakan sebagai terapi gangguan ereksi peroral Sildenafil sitrat berupa serbuk kristalin berwarna putih sampai keputihan dengan kelarutan $3,5 \mathrm{mg} / \mathrm{ml}$ dalam air. Sildenafil sitrat (1-[[3-(6,7Dihydro -1-methyl- 7-oxo-3-propyl -1Hpyrazolo [4,3-d] pyrimidin-5-yl)4thoxyphenyl]sulphonyl]-4-methyl piperazine citrate)adalah golongan obat untuk mengatasi disfungsi ereksi (DE) yang bekerja dengan cara meningkatkan kadar cyclicguanosine monophosphate (cGMP) dalam corpus cavernosum secara tidak langsung yaitu melalui penghambatan enzyme phospho diesterase tipe 5 (PDE 5) oleh meningkatnya nitrogen oksida (NO). Hal ini menimbulkan efek relaksasi otot polos dan dilatasi pembuluh darah yang menyebabkan peningkatan aliran darah ke dalam corpus cavernosum. Efek tersebut dimanfaatkan untuk pasien dengan disfungsi ereksi (Ditjen POM, 2005).

\section{METODE PENELITIAN}

\section{a. Ekstraksi sampel secara}

\section{Maserasi}

Ditimbang sampel serbuk jamu kuat lelaki kurang lebih 400 $\mathrm{mg} / \mathrm{kapsul}$, di masukkan dalam wadah maserasi, lalu di tambahkan metanol kurang lebih $5 \mathrm{ml}$. setelah 1 - 2 hari saring dan tamping ekstrak cair dari sampel jamu. 


\section{b. Identifikasi Kromatografi lapis tipis (KLT)}

Ekstrak metanol jamu kuat lelaki dan senyawa pembanding Sildenafil sitrat ditotolkan pada lempeng KLT dengan ukuran $1 \times 7$ $\mathrm{cm}$, dimasukkan ke dalam chamber yang berisi eluen Kloroform : Etanol $(9,5: 0,5)$. Setelah eluen mencapai batas tanda, angkat dan keringkan. Kemudian kromatogram yang dihasilkan diamati nodanya di bawah sinar ultra violet (UV) pada panjang gelombang $254 \mathrm{~nm}$ dan $366 \mathrm{~nm}$. Dibandingkan noda yang terdapat pada senyawa pembanding, ekstrak jamu dengan ekstrak yang di tambahkan senyawa pembanding dan perhatikan ada tidaknya kesamaan pada penampakan noda dan hitung nilai Rf-nya.

c. Penetapan kadar dengan KLTDensitometri

1. Pembuatan larutan baku Sildenafil Sitrat

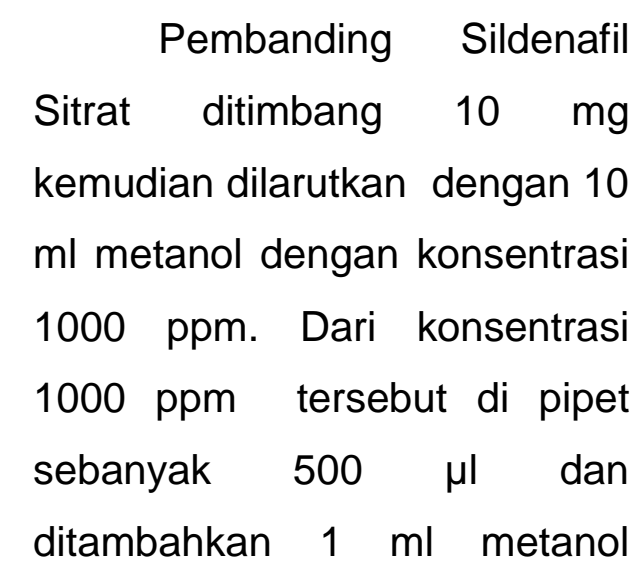

sehingga di peroleh konsentrasi 500 ppm.

\section{Pembuatan larutan sampel}

Masing-masing sampel jamu hasil meserasi di pipet sebanyak $1 \mathrm{ml}$ kemudian dilarutkan dengan $5 \mathrm{ml}$ metanol.

\section{Penentuan kadar Sildenafil} Sitrat pada sampel

Disiapkan lempeng KLT dengan ukuran $10 \times 10 \mathrm{~cm}$, dengan tepi atas ditandai 0,5 $\mathrm{cm}$ dan tepi bawah ditandai 1 $\mathrm{cm}$. Dari larutan baku dengan konsentrasi 500 ppm kemudian ditotolkan dengan menggunakan mikropipet demgan variasi konsentrasi $1 \mu \mathrm{l}$ , $2 \mu \mathrm{l}, 3 \mu \mathrm{l}$ dan $4 \mu \mathrm{l}$.Kemudian ekstrakcair jamu kuat lelaki ditotolkan dengan menggunakan mikropipet sebanyak $2 \mu \mathrm{l}$ pada lempeng $\mathrm{KLT}$ yang sama dan dilakukan replikasi sebanyak tiga kali. Lempeng di elusidalam chamber yang berisi kloroform : etanol $(9,5: 0,5)$. Noda yang terpisah diamati dengan lampu UV $254 \mathrm{~nm}$ dan diukur dengan KLT - densitometri pada panjang gelombang maksimum $292 \mathrm{~nm}$, dilakukan analisis terhadap hasil scan. 


\section{HASIL PENELITIAN}

Tabel 1: Hasil identifikasi Sildenafil sitrat dengan menggunakan metode KLT (Kromatografi Lapis Tipis).

\begin{tabular}{|c|c|c|c|c|c|c|c|c|}
\hline \multirow[t]{2}{*}{ No } & \multirow[t]{2}{*}{ Jamu } & \multicolumn{2}{|c|}{$\begin{array}{c}\text { Nilai Rf } \\
\text { Pembanding }\end{array}$} & \multicolumn{2}{|c|}{ Nilai Rf Sampel } & \multicolumn{2}{|c|}{$\begin{array}{c}\text { Nilai Rf Sampel + } \\
\text { Pembanding }\end{array}$} & \multirow{2}{*}{$\begin{array}{l}\text { Sildenafil } \\
\text { Sitrat }\end{array}$} \\
\hline & & $254 \mathrm{~nm}$ & $366 \mathrm{~nm}$ & $254 \mathrm{~nm}$ & $366 \mathrm{~nm}$ & $254 \mathrm{~nm}$ & $366 \mathrm{~nm}$ & \\
\hline 1 & Jamu I & 0,14 & 0,14 & 1,18 & $\begin{array}{l}0,80 \\
0,63 \\
0,36 \\
0,25 \\
0,18 \\
0,07\end{array}$ & $\begin{array}{l}0,18 \\
0,14\end{array}$ & $\begin{array}{l}0,80 \\
0,63 \\
0,36 \\
0,25 \\
0,18 \\
0,14 \\
0,07\end{array}$ & - \\
\hline 2 & Jamu II & 0,10 & 0,10 & 0,10 & $\begin{array}{l}0,76 \\
0,52 \\
0,34 \\
0,25 \\
0,10 \\
\end{array}$ & 0,10 & $\begin{array}{l}0,76 \\
0,52 \\
0,34 \\
0,25 \\
0,10\end{array}$ & + \\
\hline 3 & Jamu III & 0,10 & 0,10 & 0,18 & 0,18 & $\begin{array}{l}0,18 \\
0,10\end{array}$ & $\begin{array}{l}0,18 \\
0,10\end{array}$ & - \\
\hline 4 & Jamu IV & 0,14 & 1,14 & - & $\begin{array}{l}0,78 \\
0,54 \\
0,25 \\
0,10\end{array}$ & 0,14 & $\begin{array}{l}0,78 \\
0,54 \\
0,25 \\
0,14 \\
0,10\end{array}$ & - \\
\hline
\end{tabular}

Tabel 2 : Hasil Perhitungan kadar Sildenafil sitrat pada jamu kuat lelaki secara KLTDensitometri

\begin{tabular}{ccccccc}
\hline Sampel & Rf & $\begin{array}{c}\text { Luas } \\
\text { Area }\end{array}$ & $\begin{array}{c}\text { Kadar Sildenafil } \\
\text { sitrat }(\boldsymbol{\mu g})\end{array}$ & $\begin{array}{c}\text { Kadar rata-rata } \\
\text { Sildenafil sitrat }(\boldsymbol{\mu g})\end{array}$ & $\begin{array}{c}\text { Kadar } \\
\text { sildenafil sitrat } \\
\text { per kapsul }(\%)\end{array}$ \\
\hline \multirow{3}{*}{ Jamu II } & 1 & 0,28 & 5998,15 & 1,3144 & & \\
& 2 & 0,30 & 6623,01 & 1,4966 & 1,4498 & 0,00827 \\
& 3 & 0,30 & 6458,60 & 1,4489 & & \\
\hline
\end{tabular}

Gambar 1. Grafik Kurva baku Sildenafil sitrat secara KLT-Densitiome

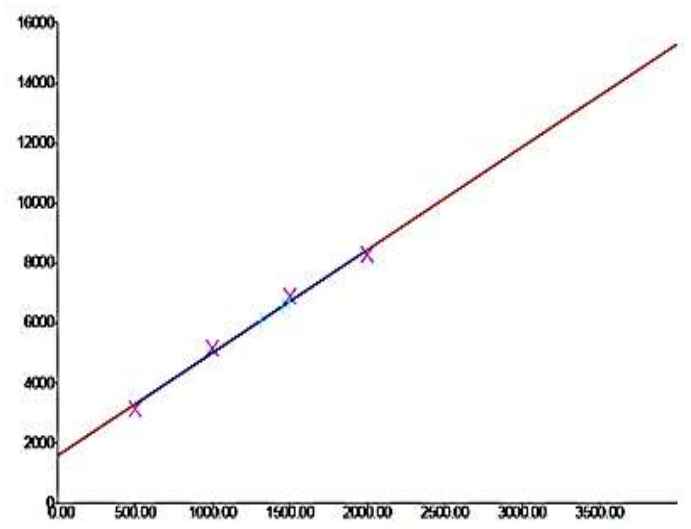

\begin{tabular}{|c|c|}
\hline Kadar $\mu \mathrm{g} / \mu \mathrm{l}$ & Area \\
\hline 0,5 & 2772,34 \\
1 & 3034,36 \\
1,5 & 3522,12 \\
2 & 4707,02 \\
\hline
\end{tabular}

$Y=1491+3.427 x$

$r=0,99628$ 
Gambar 2. Profil 2 dimensi KLT Densitometri sildenafil sitrat pada jamu kuat lelaki.

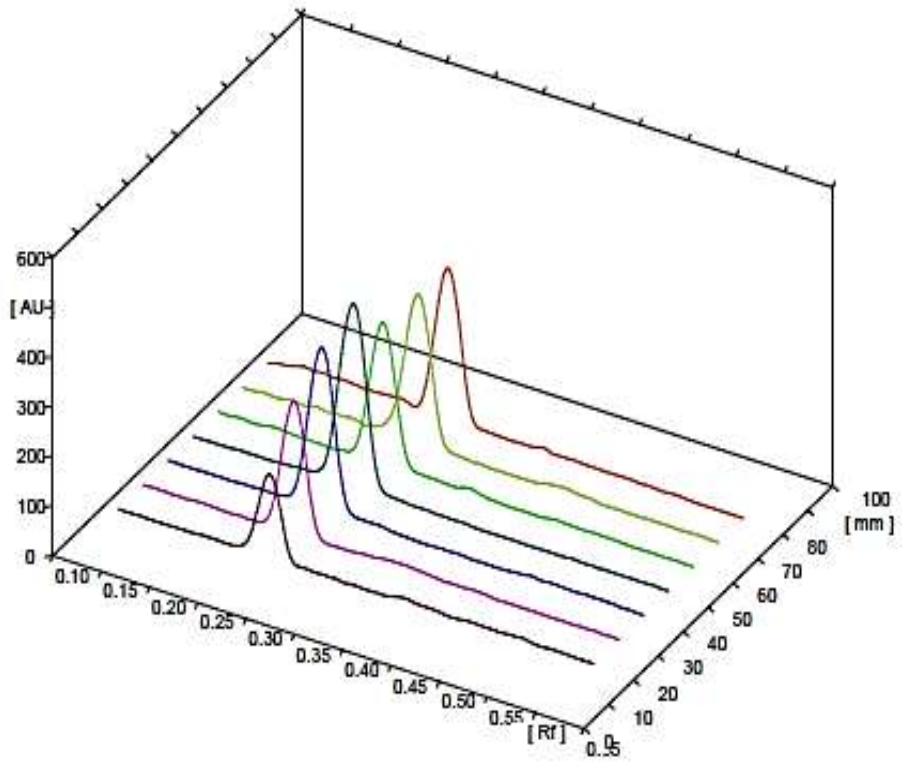

\section{PEMBAHASAN}

Analisis kuantitatif dari suatu senyawa yang telah dipisahkan dapat dilakukan dengan metode analisis instrumental berdasarkan radiasi elektromagnetik dengan analit berupa noda pada plat. Penentuan kadar suatu senyawa dapat menggunakan alat KLT-Densitometri dengan cara noda-noda yang telah terpisah pada plat dimasukkan kedalam alat tersebut kemudian ditentukan kadarnya berdasarkan hubungan Area Under Curva (AUC) masing-masing noda pada plat.

\section{Densitometri merupakan} pengukuran sifat-sifat absorbsi atau flourosensi suatu zat langsung pada kromatogram lapisan tipis menggunakan alat dengan sumber cahaya tunggal atau ganda,baik berdasarkan cahaya yang ditranmisikan maupun yang direfleksikan oleh bercak pada lempeng.

$$
\text { Mekanisme alat KLT- }
$$

Densitometri sama seperti dengan alat spektrofotometer, perbedaannya terletak pada sampel kompartemen yaitu spektrofotometer menggunakan kuvet sedangkan alat KLTdensitometri menggunakan lempeng. Rangkaiannya berupa sumber cahaya menuju monokromator untuk mengubah cahaya polikromatik menjadi monokromatik kemudian cahaya dipancarkan ke sampel kompartemen (lempeng) lalu dipantulkan, cahaya yang dipantulkan dideteksi dengan detektor dan 
diperkuat pembacaannya dengan amplivier dan hasil yang diperoleh dibaca pada layar baca atau visual display.

Bahan Kimia Obat (BKO) merupakan bahan kimia sintesis yang biasa dicampurkan pada sediaan jamu untuk menjadikan jamu tersebut semakin berkhasiat secara instan. Produk jamu yang dicampur dengan bahan-bahan kimia berbahaya ini biasa digunakan dalam mengobati berbagai penyakit seperti pegal linu, rematik, sesak napas, disfungsi ereksi, masuk angin dan pelangsing.

Bahan-bahan kimia berbahaya (BKO) yang biasa digunakan meliputi metampiron, fenilbutason, antalgin, deksametason, allopurinol, CTM, sildenafil sitrat, sibutramin hidroksida, furosemid, kofein, teofilin dan parasetamol. Dan untuk jamu kuat lelaki, bahan kimia berbahaya yang sering digunakan adalah Sildenafil sitrat.

Sildenafil sitrat atau (1-[[3- $(6,7-$ Dihydro -1-methyl- 7-oxo-3-propyl -1Hpyrazolo [4,3-d] pyrimidin-5-yl) -4ethoxyphenyl]sulphonyl]-4-methyl piperazine citrate) adalah golongan obat untuk mengatasi disfungsi ereksi (DE) yang bekerja dengan cara meningkatkan kadar cyclicguanosine monophosphate (cGMP) dalam corpus cavernosum secara tidak langsung yaitu melalui penghambatan enzyme phospho diesterase tipe 5 (PDE 5) oleh meningkatnya nitrogen oksida (NO). Hal ini menimbulkan efek relaksasi otot polos dan dilatasi pembuluh darah yang menyebabkan peningkatan aliran darah ke dalam corpus cavernosum. Efek tersebut dimanfaatkan untuk pasien dengan disfungsi ereksi.

Sildenafil Sitrat merupakan obat keras yang hanya boleh digunakan dengan resep dokter untuk mengatasi gangguan ereksi. Penggunaan yang kurang tepat dapat menyebabkan sakit kepala, muka merah, pusing, mual, nyeri perut, gangguan penglihatan, infark miokard, nyeri dada, jantung berdebar dan kematian.Tidak boleh digunakan oleh penderita gangguan jantung, stroke, dan penderita tekanan darah di bawah 90/50 $\mathrm{mmHg}$.

Metode ekstraksi yang digunakan adalah maserasi, metode ini dipilih karena digunakan untuk simplisia yang mempunyai tekstur lunak dan mengandung zat aktif yang mudah larut dalam cairan penyari. Selain itu metode ini juga digunakan karena peralatannya sederhana dan mudah diusahakan. Setelah diekstraksi diperoleh ekstrak cair untuk jamu sebanyak5 ml. Adapun pelarut 
yang digunakan yaitu metanol yang merupakan pelarut semi polar dimana pelarut yang bersifat semi polar dapat menarik semua jenis senyawa sehingga sangat baik digunakan untuk mengekstraksi.

Pada penelitian ini, dilakukan identifikasi Sildenafil sirat dengan metode kromatografi lapis tipis (KLT)dimana noda ekstrak yang ada pada lempeng KLT menunjukkan nilai Rf yang sama, berwarna biru keunguan dan sejajar dengan pembanding Sildenafil sitrat setelah dideteksi pada lampu UV 254 nm dan penentuan kadar sildenafil sitrat pada jamu kuat lelaki dilakukan menggunakan alat KLT-Densitometri, keuntungannya yaitu pengerjaannya lebih sederhana dan memiliki kepekaan tinggi dalam menganalisis senyawa yang akan dideteksi. Dalam pengerjaannya harus diperhatikan cara penotolan ekstrak dan volume yang ditotolkan harus sama.Penelitian ini bertujuan untuk mengidentifikasi bahan kimia obat (BKO) dalam hal ini Sildenafil sitrat dan menentukan berapa kadar dari senyawa tersebut.

Analisis Sildenafil sitrat secara KLT-densitometri pada panjang gelombang maksimum 292 nm diperoleh nilai $\mathrm{Rf}$ untuk pembanding Sildenafil sitrat pembanding $1 \mu \mathrm{l}, 2 \mu \mathrm{l}$ dan $3 \mu \mathrm{l}$ memiliki nilai Rf yang sama yaitu 0,27 . Untuk pembanding IV (4 $\mu$ l) dan sampel I memiliki nilai Rf yang sama yaitu 0,28 . Sedangkan Rf untuk sampel II dan III yaitu 0,30. Perbedaan nilai $\mathrm{Rf}$ disini kemungkinan pada saat mengelusi dipengaruhi oleh faktor kejenuhan camber namun perbedaan tersebut sangat kecil. Untuk penentuan kadar, diperoleh kadar ratarata dari 3 replikasi yaitu1,4208 mguntuk penotolan $2 \mu \mathrm{l}$ dan untuk kadar sildenafil sitrat per kapsul pada jamu kuat lelaki yaitu $0,00827 \mathrm{~g} / 100 \mathrm{~g}$ atau $0,00827 \%$.

\section{KESIMPULAN}

Berdasarkan hasil penelitian yang telah dilakukan maka dapat disimpulkan bahwa dari 4 jenis jamu kuat lelaki yang di identifikasi terdapat 1 jenis jamu yang positif mengandung Sildenafil sitrat yaitu jamu II dengan kadar0,00827 $\mathrm{g} / 100 \mathrm{~g}$ atau 0,00827 $\%$.per kapsul.

\section{DAFTAR PUSTAKA}

Adnan, M., 1997. Tehnik Krimatografi Untuk Analisis Bahan Makanan, Penerbit Andi, Yogyakarta

Amin, A. 2010. Obat Asli Indonesia. Farmasi UMI, Makassar.

Badawy, M, Dkk .2011. Stability Indicating Methods For The Determination Of Sildenafil Citrate In The Presence Of Its Degradation Product. Pharmacir Globale. Cairo. 
Ditjen POM. 2005. Produk llegal Yang Dicampur Bahan Kimia Obat Keras Sildenafil Sitrat. Jakarta.

Direktorat Jenderal Pengawasan Obat dan Makanan. 1986, Sediaan Galenik, Departemen Kesehatan Republik Indonesia, Jakarta.

Direktorat Jenderal Pengawasan Obat dan Makanan. 2000, Parameter Standar Umum Ekstrak Tumbuhan Obat, Departemen Kesehatan Republik Indonesia, Jakarta.

Gritter, R.J., 1991, Pengantar kromatografi, Terjemahan Padmawinata, Edisi Ketiga, Institut Teknologi Bandung, Bandung.

Ganiswarna, S. 2007. Farmakologi dan Terapi Edisi V. Universitas Indonesia; Jakarta.

Gennaro, A. 2005. Remington The Science and Practice of Pharmacy $21^{\text {st }}$ Edition.A Wolters Kluwer Company; Phyladelphia.

Guyton, A. 1996. Fisiologi manusia dan Mekanisme Penyakit. ECG Penerbit Buku Kedokteran; Jakarta.

Harmoto N, dkk. 2006. Herbal dan Jamu (Pengaruh dan Efek Sampingnya),http://www.ningha rmanto.com/bukumade/Pilih Jamu danHerbal_Tanpa_Efek_Sampi ng.pdf. Diakses 27 Maret 2012.
Najib, A. 2009. Waspadai Bahan Kimia yang Dioplos dalam Jamu.http://nadjeeb.word press.com/2009/10/15/waspada i-bahan-kimia-yang-dioplosdalam-jamu/. Diakses tanggal 3 Februari 2012.

Rohman. 2007. Kimia analisis farmasi. Yogyakarta : Pustaka Pelajar.

Sastrohamidjoyo, $\quad$ H. 1985. Kromatografi,Liberty. Yogyakarta.

Schunack, W. 1990. Buku pelajaran kimia farmasi (Edisi 2). Yogyakarta : Universitas Gadjah Mada.

Sherma, J. 1994. Handbook of ThinLayer Chromatography Third Edition. New York : Marcel Dekker Inc.

Sukandar E Y. 2006. Tren dan Paradigma Dunia Farmasi, Industri Klinik Teknologi Kesehatan, disampaikan dalam orasi ilmiah Dies Natalis ITB, http://itb.ac.id/focus/focus_file/or asi-ilmiah-dies-45.pdf, diakses 27 maret 2012.

Tjay. 2008. Obat-obat Penting Edisi V. Depkes RI : Jakarta

Tjitrosoepomo, G., 1989, Taksonomi Tumbuhan Obat-Obatan, Universitas Gaja Mada Press, Yogyakarta.

WHO, 2003, Traditional medicine, http://www.who.int/mediacentre/ factsheets/fs134/en/,diakses 16 Februari 2012. 